\title{
The Relationship between Nitrogenase and Glutamine Synthetase in Bacteroids of Rhizobium leguminosarum of Various Ages
}

\author{
By KEES PLANQUÉ,* GERT E. DE VRIES AND JAN W. KIJNE \\ Research Group of Nitrogen Fixation, Botanical Laboratory, \\ State University, Leiden, The Netherlands
}

(Received 10 December 1977)

\begin{abstract}
The activities of nitrogenase, glutamine synthetase and other ammonia-assimilating enzymes were studied in bacteroids of Rhizobium leguminosarum isolated 9 to $21 \mathrm{~d}$ after infection. Total bacteroid numbers (per plant) increased proportionally with nitrogenase, but glutamine synthetase activity decreased with increasing age of the root nodule. Glutamine synthetase was adenylylated throughout the period of increasing nitrogenase activity and during the period of constant nitrogenase activity.
\end{abstract}

\section{INTRODUCTION}

Cultures of the genus Rhizobium have two systems for assimilating ammonia: ATPindependent glutamate dehydrogenase with low affinity for ammonia, and an ATP-dependent system with high affinity for ammonia which operates through the concerted action of glutamine synthetase and glutamate synthase (Brown \& Dilworth, 1975). The presence of both systems is regulated by the exogenous ammonia concentration.

Leguminous plants become independent of supplied ammonia after infection with rhizobia and establishment of an effective symbiosis, in which the invading bacteria develop into non-dividing, ammonia-producing bacteroids. However, bacteroids of Rhizobium leguminosarum contain insufficient amounts of ammonia-assimilating enzymes to cope with all the newly fixed nitrogen (Kurz, Rokosh \& La Rue, 1975; Brown \& Dilworth, 1975; Planque et al., 1977). The excess ammonia is thought to be assimilated by an enzyme system consisting of glutamine synthetase, glutamate synthase and asparagine synthetase present in the plant fraction of root nodules (Scott, Farnden \& Robertson, 1976; Robertson, Warburton \& Farnden, 1975).

Glutamine synthetase has a dual role in some bacteria. In addition to its role in the production of glutamine from glutamate and ammonia, it controls the synthesis of some enzymes concerned with the breakdown of substrates used as nitrogen sources, e.g. histidase and proline oxidase (Magasanik, Prival \& Brenchley, 1973). Nitrogenase synthesis is also considered to be under the control of glutamine synthetase (Shanmugam \& Valentine, 1975). Mutants of Klebsiella pneumoniae with altered regulation of glutamine synthetase could not synthesize nitrogenase, and mutants of $K$. aerogenes constitutive for glutamine synthetase, which acquired the nif genes by genetic transfer, showed constitutive expression of these nif genes (Tubb, 1974). Results obtained for a $R$. meliloti mutant with low glutamine synthetase activity and a 'cow pea' Rhizobium lacking glutamine synthetase activity, both of which were deficient in nitrogenase, also indicate the involvement of glutamine synthetase in the regulation of nitrogenase synthesis (Kondorosi et al., 1977; Ludwig \& Signer, 1977).

\footnotetext{
* Present address: Department of Biochemistry, State University, Leiden, The Netherlands.
} 
This paper describes studies of the activities of glutamine synthetase and nitrogenase during the transition of bacteria into bacteroids, using the techniques of Planqué \& van Brussel (1976) to achieve simultaneous development of root nodules resulting in bacteroid preparations of reproducible age distribution.

\section{METHODS}

Bacteroids of Rhizobium leguminosarum strain A171 were produced by inoculation of pea seeds, Pisum sativum cv. Rondo, using growth conditions described previously (Planqué \& van Brussel, 1976).

Bacteroids were isolated and purified as described by Planqué et al. (1977) except that $50 \mathrm{mM}-\mathrm{Tris} / \mathrm{HCl}$ buffer, $\mathrm{pH} 7 \cdot 4$, was used instead of phosphate buffer. The purified bacteroids were resuspended in $50 \mathrm{~mm}-\mathrm{N}$ 2-hydroxyethylpiperazine- $N^{\prime}$-2-ethanesulphonic acid (HEPES) buffer, pH 7·4. Electron microscopic examination showed the final bacteroid preparation to be free from plastid and mitochondrial contamination (Planqué et al., 1977).

Enzymic activities (excluding nitrogenase) were determined in cell-free homogenates prepared by sonicating the bacteroid suspension for $45 \mathrm{~s}$ and removing the debris by centrifuging at $50000 \mathrm{~g}$ for $45 \mathrm{~min}$. The total bacteroid material isolated was determined by measuring the absorbance at $617 \mathrm{~nm}$ of a diluted sample of the bacteroid suspension prior to sonication, and converting this absorbance to bacteroid numbers using a calibration curve. Viable bacteria inside the root nodules were counted by the method of Vincent (1970). Duplicate samples of two root systems were sterilized for $3 \mathrm{~min}$ in $0 \cdot 1 \%(\mathrm{w} / \mathrm{v}) \mathrm{HgCl}_{2}$, and then homogenized in sterile water with an Elvehjem-Potter homogenizer. After removal of plant residue by filtration, appropriate dilutions were plated on mannitol/glucose/yeast extract agar (van Brussel, Planqué \& Quispel, 1977).

Glutamine synthetase (EC 6.3.1.2) was determined by the transferase assay in the presence of $\mathrm{Mn}^{2+}$ (Shapiro \& Stadtman, 1970). The average state of adenylylation was determined by carrying out the transferase assay in the presence of either $0.3 \mathrm{mM}-\mathrm{Mn}^{2+}$ or $0.3 \mathrm{mM}-\mathrm{Mn}^{2+}$ plus $60 \mathrm{mM}-\mathrm{Mg}^{2+}$ and determining the ratio of the two values (Stadtman et al., 1970).

Nitrogenase was assayed by acetylene reduction using 10 plants selected at random from a large culture. Roots were cut under the cotyledons and incubated for up to $20 \mathrm{~min}$ under $10 \%$ (v/v) acetylene in air. Acetylene reduction was linear over this period. With the gas chromatographic procedures used (Planque \& van Brussel, 1976), an increase of 0.1 nmol ethylene could be detected.

Glutamate synthase (EC 2.6.1.53) and glutamate dehydrogenase (EC 1.4.1.4) were determined as described previously (Planqué et al., 1977).

Protein was determined by a modified Folin procedure (Lowry et al., 1951; Benzadoun \& Weinstein, 1976).

\section{RESULTS}

\section{Plant culture}

As the plants were cultivated at an initial high level of medium in the growth-bin, root growth was inhibited, resulting in initiation of root nodules over a relative short piece of the main root (Planqué \& van Brussel, 1976). At the proximal side of the meristem of R. leguminosarum root nodules, cells are infected by bacteria, resulting in an approximately constant number of young bacteroids. The amount of mature bacteroid tissue per plant increases up to $21 \mathrm{~d}$ after infection (Kijne, 1975a,b). This method of cultivation resulted in an almost synchronized development of the bacteroid tissue providing the experimenter with reproducible numbers of bacteroids on specific days after inoculation.

\section{Development of bacteria and bacteroids in nodules}

Preliminary experiments showed that surface sterilization of root nodules for up to $3 \mathrm{~min}$ resulted in a considerable decrease in the number of viable bacteria. Prolonged sterilization, for up to $20 \mathrm{~min}$, had little further effect on the numbers of bacteria, but a period of $30 \mathrm{~min}$ resulted in complete sterilization of the nodule. This biphasic decrease in numbers of bacteria was taken to indicate that sterilization for up to 3 min killed organisms on the surface without significantly affecting the numbers of internal bacteria. We therefore sterilized the root nodules for $3 \mathrm{~min}$ before homogenization for measurements of the numbers of bacteria inside the nodules. 


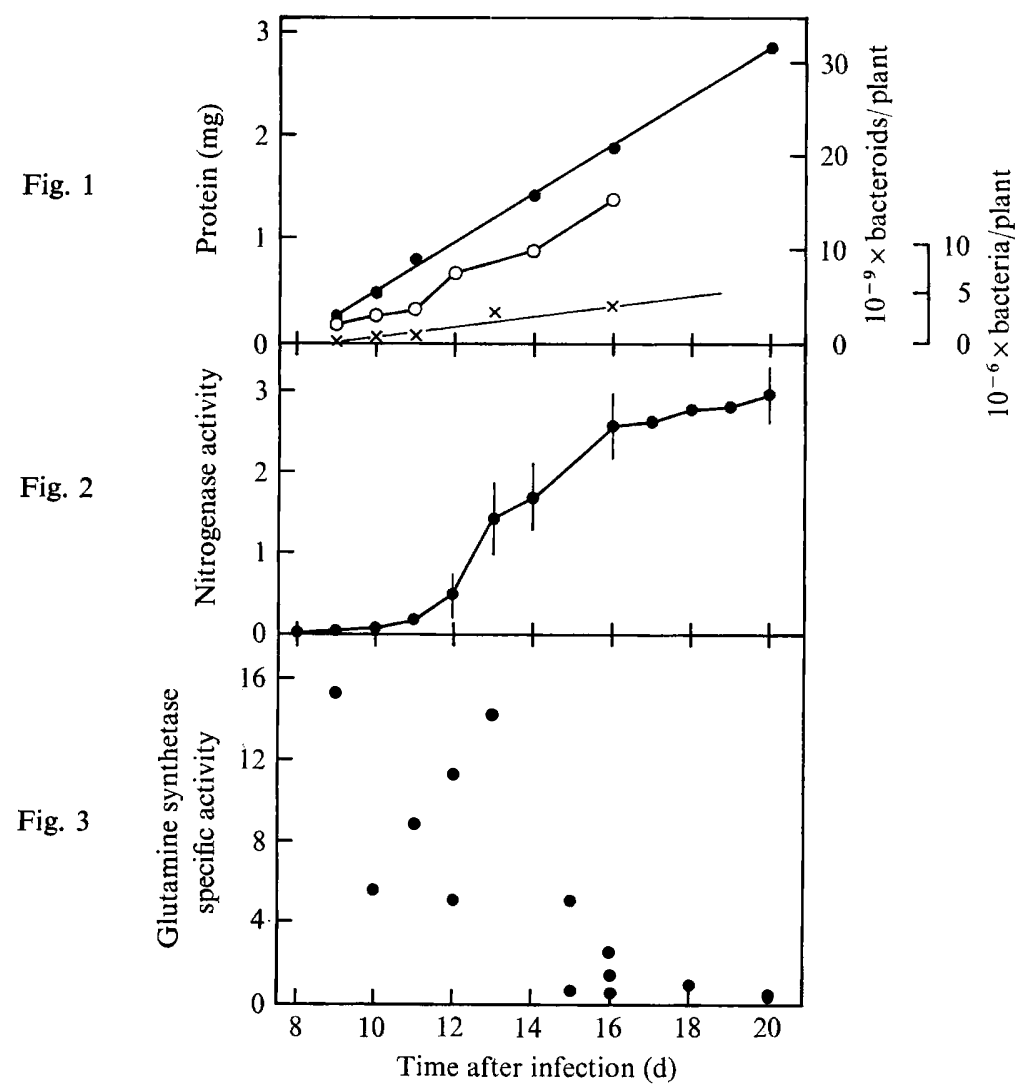

Fig. 1. Numbers of bacteria $(x)$ and bacteroids $(\Theta)$ inside roots of Pisum sativum, and protein content $(O)$ of sonic extract of bacteroids.

Fig. 2. Nitrogenase activity in plants of various ages; bars indicate the variation between samples of the same age. Activities (per plant) are expressed as $\mu$ mol acetylene reduced $\mathrm{h}^{-1}$.

Fig. 3. Specific activity of glutamine synthetase in bacteroid cytoplasm, determined as $\mathrm{Mn}^{2+}$ activated $\gamma$-glutamyl transferase. Activities are expressed as nmol $\gamma$-glutamyl hydroxamate formed (mg protein) $)^{-1} \min ^{-1}$.

Numbers of bacteria increased from $0.4 \times 10^{6}$ at day 9 to $4 \times 10^{6}$ at day 16 , while bacteroid numbers increased from $2 \cdot 4 \times 10^{9}$ per plant at day 9 to $30 \cdot 2 \times 10^{9}$ at day 20 (Fig. 1). Bacterial numbers never exceeded $0.02 \%$ of the number of bacteroids. The increase in bacteroid numbers was accompanied by a linear increase in soluble protein in the supernatant of disrupted bacteroids (Fig. 1).

\section{Development of enzymic activities}

Nitrogenase was first detected $9 \mathrm{~d}$ after infection. Initially the increase in activity was low, but between days 11 and 16 a rapid increase was observed (Fig. 2). The steady state activity at day 20 was 2.5 to $3.5 \mu \mathrm{mol}$ acetylene reduced per plant $\mathrm{h}^{-1}$.

Glutamine synthetase showed a notable variation between bacteroids of the same age isolated from different plant cultures. Attempts to minimize the variation by optimizing the assay conditions were unsuccessful. Despite this variation, we concluded from Fig. 3 that specific activities were higher in young bacteroids ( 9 to $12 \mathrm{~d}$ ) and that activity was negligible after day 16. In previous experiments, we reported the absence of biosynthetic activity in bacteroids isolated at day 21, using the synthetase assay (Planqué et al., 1977). 


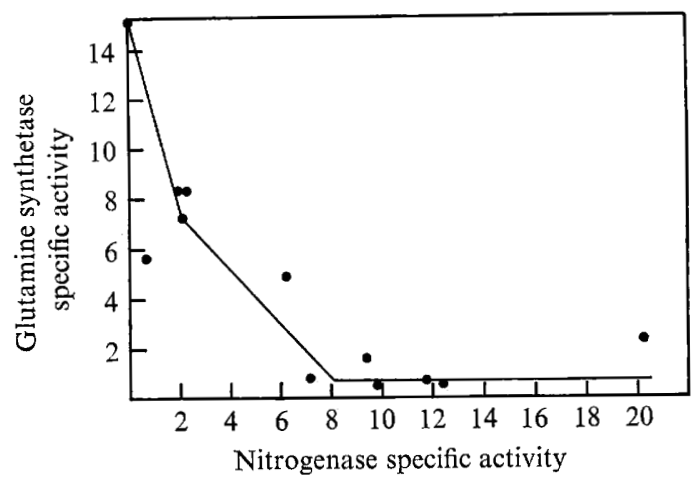

Fig. 4. Relation between nitrogenase and glutamine synthetase specific activities. Nitrogenase specific activities [in nmol ( $\mathrm{mg}$ protein $)^{-1} \mathrm{~min}^{-1}$ ] were determined by dividing the nitrogenase activity of intact plants by the protein concentration of bacteroid cytoplasm of plants of the same culture and age.

As a further control on the adenylylation state of glutamine synthetase, we assayed the enzyme in the presence of either $0.3 \mathrm{mM}-\mathrm{Mn}^{2+}$ or $0.3 \mathrm{mM}-\mathrm{Mn}^{2+}$ plus $60 \mathrm{mM}-\mathrm{Mg}^{2+}$ at days 10,14 and 21 . The $\mathrm{Mn}^{2+}$ plus $\mathrm{Mg}^{2+}$ activated assays showed no significant activity at all ages of the bacteroids.

There was a reciprocal relationship between the specific activities of nitrogenase [converted from acetylene reduction data as described by Planqué et al. (1977)] and glutamine synthetase (Fig. 4). Where acetylene reduction and glutamine synthetase activities were determined on the same samples, much less variation was observed than one would expect from Fig. 3. Glutamate synthase was absent from all samples investigated.

Glutamate dehydrogenase activity was always detected. The total activity, expressed on a per plant basis, showed a small increase from $0 \cdot 1$ to $1.0 \mathrm{nmol} \mathrm{NADH}$ oxidized $\mathrm{min}^{-1}$ between days 9 and 14 after which it fluctuated between 2 and $6.5 \mathrm{nmol} \mathrm{NADH}$ oxidized $\min ^{-1}$. The specific activity decreased. With the exception of the sample on day 9 , the specific activities were inadequate to account for the assimilation of newly fixed nitrogen.

\section{DISCUSSION}

The co-development of total bacteroid numbers, bacteroid protein and nitrogenase during maturation of bacteroid tissue concurs with the anatomical evidence that development of bacteroid tissue in this Pisum sativum-Rhizobium leguminosarum symbiosis, under greenhouse conditions, continues until breakdown of the oldest bacteroid tissue starts after about $21 \mathrm{~d}$ (Kijne, 1975b). In a similar experiment on age dependency of nitrogenase and ammonia-assimilating enzymes, Kurz et al. (1975) also found a time-dependent relationship between these enzymes. However, their experiments were done under field conditions over a 13-week period and in this system secondary infections on lateral roots would disturb the general pattern of development in bacteroid tissue, resulting in a less clear relationship. The experiments presented here show a strict relationship between the activity of glutamine synthetase and nitrogenase and the age of bacteroid tissue in this symbiotic association.

Glutamine synthetase and glutamate dehydrogenase lose specific activity during the increase in bacteroid numbers. It is unlikely that either enzyme plays a significant assimilatory role. Glutamate dehydrogenase has too high an apparent $K_{\mathrm{m}}$ for ammonia (Dunn \& Klucas, 1973; Brown \& Dilworth, 1975) and glutamine synthetase is present in a catalytically inactive form. The glutamine synthetase of $R$. leguminosarum is thus different from that of 
R. japonicum bacteroids and 'cow pea' Rhizobium in that the enzymes from the latter two species have low adenylylation numbers (Bishop et al., 1976; Bergersen \& Turner, 1976) in, respectively, active nitrogen-fixing bacteroids and free-living nitrogen-fixing bacteria, whereas this study and that of Kurz et al. (1975) has shown that glutamine synthetase in $R$. leguminosarum is highly adenylylated. Increasing the ammonia concentration, whether applied to intact nodules or to isolated bacteroids, did not affect the degree of adenylylation in $R$. japonicum bacteroids, although it did affect the nitrogenase activity suggesting that the adenylylation cascade system does not function in the bacteroids (Bishop et al., 1976). In the free-living nitrogen-fixing 'cow pea' Rhizobium grown in continuous culture, excess ammonia also had no effect on the degree of adenylylation provided that stringent oxygen limitation was maintained. Increasing oxygen concentration, however, resulted in inactivation of the glutamine synthetase by adenylylation (Bergersen \& Turner, 1976). These bacteria are supposedly dividing in contrast to the bacteroids of root nodules. Ludwig \& Signer (1977) demonstrated that in free-living 'cow pea' Rhizobium, nitrogenase activity did not appear before the cells had reached the stationary phase of growth and therefore the nitrogenase activity shown in the continuous culture experiments of Bergersen \& Turner (1976) could be attributed to a non-dividing population of cells.

The results presented here show inactive glutamine synthetase at all ages of bacteroids investigated.

The validity of the transferase reaction for the assay of glutamine synthetase has been doubted (Miflin \& Lea, 1977; Darrow, Knotts \& Jarrel, 1976) and extrapolation of the assay conditions for E. coli to Rhizobium may not result in optimal determination of the state of adenylylation in Rhizobium. However, glutamine synthetase activity was also not detected using the synthetase assay in pea bacteroids (Planqué et al., 1977).

Kondorosi et al. (1977) found no evidence for the functioning of an adenylylation cascade system in Rhizobium meliloti in batch culture experiments. Changes in the state of adenylylation in intact cells, which could be prevented by the use of cetyltrimethylammonium bromide (Bender et al., 1977), have been observed in $R$. leguminosarum, indicating the presence of an active adenylylating system (de Vries \& Schouten, unpublished results).

The disappearance of glutamine synthetase from the bacteroids is probably due to the absence of synthesis of the enzyme during and after the transition of bacteria to bacteroids.

The hypothesis that in Rhizobium symbiosis the de-adenylylated glutamine synthetase has to be present to derepress nitrogenase synthesis is not supported by the results presented here. Possibly de-adenylylated glutamine synthetase is present in very young bacteroids sufficient to derepress nitrogenase synthesis during the active life span of the bacteroid but in an amount which escapes detection in the assay.

The dependence of glutamine synthetase activity on bacteroid age should be taken into account in future studies of this enzyme in bacteroids.

The authors wish to thank the Netherlands Organization for the Advancement of Pure Research (Z.W.O.) and Foundation for Biological Research (B.I.O.N.) for financial support, Annelies Burgers and Jacques van Nierop for skilful technical assistance, and John V. Ellert for the production of plants. 


\section{REFERENCES}

Bender, R. A., Janssen, K. A., Resnick, A. D., Blumenberg, M., Foor, F. \& Magasanik, B. (1977). Biochemical parameters of glutamine synthetase from Klebsiella aerogenes. Journal of Bacteriology 129, 1001-1009.

Benzadoun, A. \& Weinstein, D. (1976). Assay of proteins in the presence of interfering materials. Analytical Biochemistry 70, 241-247.

BERGERSEN, F. \& TuRner, G. L. (1976). The role of $\mathrm{O}_{2}$ limitation in control of nitrogenase in continuous cultures of Rhizobium sp. Biochemical and Biophysical Research Communications 73, 524-531.

Bishop, P. E., Guevara, J. G., Engelke, J. A. \& EvaNs, H. J. (1976). Relation between glutamine synthetase and nitrogenase activities in the symbiotic association between Rhizobium japonicum and Glycine max. Plant Physiology 57, 542-546.

Brown, C. M. \& DilworTh, M. J. (1975). Ammonia assimilation by Rhizobium cultures and bacteroids. Journal of General Microbiology 86, 3948.

van Brussel, A. A. N., Planqué, K. \& Quispel, A. (1977). The walls of Rhizobium leguminosarum in bacteroid and free-living forms. Journal of General Microbiology 101, 51-56.

Darrow, R. A., KNotts, R. R. \& Jarrel, S. O. (1976). The significance of $\gamma$-glutamyl transferase activity in extracts of enteric bacteria, root nodule bacteria and isolated bacteroids. Plant Physiology 57, 70, report 366 .

DunN, S. D. \& Klucas, R. V. (1973). Studies on the possible routes of ammonia assimilation in soy bean root nodule bacteroids. Canadian Journal of Microbiology 19, 1493-1499.

Kondorosi, A., SvÁB, Z., Kiss, G. B. \& Dixon, R. A. (1977). Ammonia assimilation and nitrogen fixation in Rhizobium meliloti. Molecular and Genera Genetics 151, 221-226.

KIJNE J. W. (1975a). The fine structure of pea root nodules. I. Vacuolar changes after endocytotic host cell infection in Rhizobium leguminosarum. Physiological Plant Pathology 5, 75-79.

KIJNE, J. W. (1975b). The fine structure of pea root nodules. II, Senescence and disintegration of the bacteroid tissue. Physiological Plant Pathology 7, 17-21.

Kurz, W. G., Rokosh, D. A. \& La Rue, T. A. (1975). Enzymes of ammonia assimilation in Rhizobium leguminosarum bacteroids. Canadian Journal of Microbiology 21, 1009-1012.
Lowry, O. H., Rosebrough, N. J., FArR, A. L. \& Randall, R. J. (1951). Protein measurement with the Folin phenol reagent. Journal of Biological Chemistry 193, 265-275.

LúdwiG, R. A. \& Signer, E. R. (1977). Glutamine synthetase and control of nitrogen fixation in Rhizobium. Nature, London 267, 245-248.

Magasanik, B., Prival, M. J. \& Brenchley, J. E. (1973). Glutamine synthetase, regulator of the synthesis of glutamate-forming enzymes. In The Enzymes of Glutamine Metabolism, pp. 65-70. Edited by S. Prusiner and E. R. Stadtman. New York: Academic Press.

Miflin, B. J. \& LeA, P. J. (1977). Amino acid metabolism. Annual Review of Plant Physiology 28, 299-329.

Planqué, K. \& van Brussel, A. A. N. (1976). An improved large-scale isolation procedure for bacteroids of Rhizobium leguminosarum Frank from Pisum sativum L. Plant and Soil 45, 309-315.

Planqué, K., Kennedy, I. R., de VRIes, G. E., Quispel, A. \& VAN Brussel, A. A. N. (1977). Location of nitrogenase and ammonia assimilatory enzymes in bacteroids of Rhizobium leguminosarum and Rhizobium lupini. Journal of General Microbiology 102, 95-104.

Robertson, J. G., Warburton, M. P. \& FARnden, K. J. F. (1975). Induction of glutamate synthase during nodule development in lupins. FEBS Letters 55, 33-37.

Scott, D. B., Farnden, K. J. F. \& Robertson, J. G. (1976). Ammonia assimilation in lupin nodules. Nature, London 263, 703-706.

Shanmugam, K. T. \& Valentine, R. C. (1975). Molecular biology of nitrogen fixation. Science 187, 919-924.

Shapiro, B. M. \& Stadtman, E. R. (1970). Glutamine synthetase (Escherichia coli). Methods in Enzymology XVIIA, 910-922.

Stadtman, E. R., Ginsburg, A., Ciardi, J. E., Yeh, J., Henning, S. B. \& Shapiro, B. M. (1970) Multiple molecular forms of glutamine synthetase produced by enzyme catalyzed adenylylation and deadenylylation reactions. Advances in Enzyme Regulation 8, 99-118.

TuBB, R. S. (1974). Glutamine synthetase and ammonia regulation of nitrogenase synthesis in Klebsiella. Nature, London 251, 481-485.

Vincent, J. M. (1970). A Manual for the Practical Study of Root Nodule Bacteria. Oxford: Blackwell Scientific Publications. 